\title{
TINJAUAN TERHADAP PENGELOLAAN SAMPAH
}

Ashabul Kahfi

\author{
Universitas Islam Negeri (UIN) Alauddin Makassar
}

Email: cavon.al@gmail.com

\begin{abstract}
The garbage problem is endless. The problems faced not only in Indonesia but around the world. Continuous waste production increases with population growth, changes in consumption patterns, and people's lifestyles. The identified issues include increasing the amount of waste generation, the type, and the diversity of garbage characteristics. The next problem is related to the paradigm of society to (management) waste, until the existence of rules related to waste management. In developed countries efforts have been made to resolve the issue. The birth of $3 R$ concept adopted by Indonesia into $3 M$ Principle.

Keywords: Garbage, Garbage Problems, Waste Management
\end{abstract}

\begin{abstract}
Abstrak
Masalah sampah memang tidak ada habisnya. Permasalahan yang tengah dihadapi tidak hanya di Indonesia saja, tapi di seluruh dunia. Produksi sampah yang terus menerus meningkat seiring dengan pertambahan jumlah penduduk, perubahan pola konsumsi, dan gaya hidup masyarakat. Permasalahan yang teridentifikasi meliputi meningkatkan jumlah timbulan sampah, jenis, dan keberagaman karakteristik sampah. Permasalahan selanjutnya adalah terkait paradigma masyarakat terhadap (pengelolaan) sampah, hingga keberadaan aturan terkait pengelolaan sampah. Di Negara-negara maju telah dilakukan berbagai upaya untuk mengatasi masalah tersebut. Lahirnya konsep 3R yang diadopsi oleh Indonesia menjadi Prinsip 3M.
\end{abstract}

Kata Kunci : Sampah, Permasalahan Sampah, Pengelolaan Sampah 


\section{PENDAHULUAN}

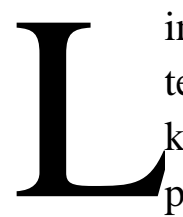

ingkungan hidup dan permasalahannya merupakan suatu kondisi yang tengah dihadapi oleh umat manusia, baik dalam lingkup regional kedaerahan, nasional maupun global. Pembangunan, laju pertumbuhan penduduk, perkembangan teknologi, pola hidup dan konsumsi merupakan rangkaian yang oleh beberapa kalangan dianggap sebagai penyebab permasalahan lingkungan tersebut. Jika dilihat, akan tampak bahwa persoalan lingkungan hidup mungkin saja timbul akibat proses pembangunan saja secara parsial, sebab yang disebut sebagai pembangunan pada dasarnyaa adalah melakukan perubahan. Akan tetapi jika disimak secara menyeluruh pembangunan ternyata tidak berdiri sendiri, sebab pada bahagian lain aspek pertumbuhan ekonomi, meningkatnya jumlah penduduk termasuk pola konsumsinya, serta kemajuan teknologi justru dipergunakan sebagai indikator keberhasilan suatu pembangunan, dan pada sisi inilah seringkali terjadi benturan dengan permasalahan lingkungan hidup.

Sebelumnya orang menduga masalah lingkungan global lebih banyak dipengaruhi faktor alam, seperti iklim, yang mencakup temperatur, curah hujan, kelembaban, tekanan udara, tofografi, geografis dan lainnya. Belakangan orang mulai menyadari bahwa aktifitas manusia pun mempengaruhi iklim dan lingkungan secara signifikan. Contoh penebangan hutan, mempengaruhi perubahan suhu dan curah hujan secara lokal yang akhirnya menyebabkan terjadinya banjir. Ketika area hutan yang hilang semakin luas, maka akibat yang ditimbulkan bukan lagi lokal tapi sudah berskala regional hingga pada akhirnya berkembang ke skala global.

Isu lingkungan hidup menjadi sebuah topik dikarenakan adanya kesadaran bahwa jumlah penduduk yang terus meningkat mengakibatkan aktivitas sosial ekonomi manusia yang mengancam lingkungan juga meningkat. Faktor terpenting dalam permasalahan ini adalah besarnya populasi manusia (laju pertumbuhan penduduk).

Pertumbuhan penduduk memiliki arti pertumbuhan kawasan urban yang berimplikasi pada kebetuhan akan ketersediaan lahan, juga kebutuhan tambahan produksi pangan. Belum lagi ada peningkatan kebutuhan energi. Pada masingmasing kebutuhan ini ada implikasi pada lingkungan. Terlepas dari implikasi yang muncul akibat pembangunan dan industrialisasi, yang tampak nyata adalah angka pertumbuhan penduduk yang menunjukkan kenaikan dari tahun ke tahun. Laju pertumbuhan penduduk yang pada gilirannya akan meningkatkan beragam kebutuhan dan sejalan dengan itu akan meningkatkan jumlah buangan/residu atau 
sisa, baik dari proses konsumsi maupun hasil dari aktifitas yang dilakukan, berupa sampah. ${ }^{1}$ Secara sederhana, sampah diartikan sebagai material sisa yang tidak diinginkan (akhirnya dibuang) setelah suatu proses selesai atau berakhir, sehingga dapat dinyatakan bahwa sampah adalah konsep yang ditujukan pada manusia sekaligus konsekuensi dari adanya olah aktifitas manusia. ${ }^{2}$

Terkait pada peningkatan volume sampah adalah jenis dan ragam, spesifikasi serta karakteristik sampah yang bertambah dari waktu ke waktu seiring bermunculannya material dan bahan bahan baru yang pada gilirannya membutuhkan sistem pengolahan dan penanganan yang berbeda dari sebelumnya, semisal sampah plastik atau sampah elektronik, belum lagi buangan lainnya yang dikategorikan sebagai limbah terutama limbah bahan berbahaya dan beracun (B3) yang tentunya membutuhkan penanganan khusus dan lebih spesifik dibandingkan sampah domestik lainnya. Oleh sebab itu, permasalahan kebersihan dan kesehatan lingkungan (termasuk sampah) merupakan permasalahan kompleks yang tengah dihadapi oleh semua negara, tak terkecuali Indonesia. Indonesia sebagai negara berpenduduk terpadat ke 4 (empat) diperhadapkan pada permasalahan pengelolaan sampah yang mencapai 200.000 ton / hari ${ }^{3}$, bahkan berdasarkan Riset yang dipublikasikan di jurnal Science pada 13 Februari 2015 terungkap bahwa Indonesia merupakan penyumbang terbesar kedua sampah plastik di lautan ${ }^{4}$. Sementara itu, terjadinya ketidakseimbangan antara buangan (sampah yang dihasilkan), pengangkutan, dan pengelolaan secara umum menjadikan permasalahan ini menjadi kian kompleks khususnya di kota-kota besar di Indonesia.

1 Republik Indonesia, Undang-undang Nomor 18 Tahun 2008 tentang Pengelolaan Sampah. Pasal 1 ayat (1) menyatakan "sampah adalah sisa kegiatan sehari/hari manusia dan/atau proses alam yang berbentuk padat"

${ }^{2}$ Bandingkan dengan pengertian limbah berdasarkan Undang Undang No. 32 Tahun 2009 Tentang Perlindungan dan Pengelolaan Lingkungan Hidup. Pasal 1 ayat (20), yang menyatakan bahwa limbah adalah sisa suatu usaha dan kegiatan.

3 http://nasional.republika.co.id/berita/nasional/umum/16/04/12/o5iwdp334-indonesiahasilkan-200-ribu-ton-sampah-per-hari. Diakses tanggal 8 Maret 2017

4 http://nationalgeographic.co.id/berita/2016/08/indonesia-penghasil-sampah-plastikkedua-terbesar-di-dunia. Diakses tanggal 8 Maret 2017. Lihat juga Hasil riset Jenna R Jambeck dan kawan-kawan (publikasi di www.sciencemag.org 12 Februari 2015) yang diunduh dari laman www.iswa.org pada 20 Januari 2016,yang menyebutkan Indonesia berada di posisi kedua penyumbang sampah plastik ke laut setelah Tiongkok, disusul Filipina, Vietnam, dan Sri Lanka. 
Misalnya salah satu kota besar yaitu Kota Makassar, dengan jumlah penduduk sebanyak $1652970^{5}$ jiwa, turut pula merasakan permasalahan sampah sebagai suatu permasalahan yang memerlukan perhatian serius. Dengan jumlah penduduk terbanyak ke 5 (lima) diantara 10 kota besar di Indonesia, maka sampah yang dihasilkan pada tahun 2016 berkisar antara 700 hingga 800 ton per hari naik dua kali lipat dibanding tahun 2015 yang berkisar 400 ton per hari. ${ }^{6}$

Dalam Islam terdapat ungkapan yang sangat familiar dan populer yaitu "kebersihan adalah sebagian dari iman"7, sebuah ungkapan yang sudah diperkenalkan dan diajarkan oleh orang tua kepada anaknya sejak dini, yang terkait pada pemahaman sederhana misalnya menggosok gigi, mencuci tangan sebelum makan, mencuci kaki sebelum tidur, mandi sampai pada membersihkan rumah dan membuang sampah pada tempatnya (tidak membuang sampah sembarangan).

Berdasarkan paparan latarbelakang tersebut, tampak bahwa permasalahan lingkungan secara umum timbul akibat berbagai kondisi, baik itu yang bersifat alamiah maupun akibat ulah manusia dan segala aktifitasnya. Berkesesuaian dengan hal tersebut adalah sampah, yang oleh UU No. 18 tahun 2008 (UU Sampah) diartikan sebagai sisa, baik yang dihasilkan oleh manusia maupun oleh proses alam. Hal mendasar yang menjadi permasalahan selanjutnya adalah langkah-langkah penanganan sampah yang dapat saja berupa program-program strategis pengelolaan sampah.

\section{PEMBAHASAN}

Secara sederhana, sampah merupakan materi, bahan maupun segala sesuatu yang tidak diinginkan, baik itu merupakan sisa atau residu maupun buangan. Meski demikian, dalam konsep perundang-undangan, sampah dapat pula

\footnotetext{
${ }^{5}$ http://dukcapil-makassar.com/index.php/data-penduduk/list/2, diakses tanggal 8 Maret 2017

${ }^{6}$ Meningkatnya jumlah volume sampah ini didasarkan pada volume sampah yang masuk ke TPA Tamangapa. Lihat http://regional.liputan6.com/read/2440317/produksi-sampah-makassarmelonjak-100-daya-tampung-tpa-minim.

${ }^{7}$ Terlepas dari persoalan anggapan bagi sebagian umat Islam terkait hadits atau hanya sekedar ungkapan. Akan tetapi terdapat beberapa hadits yang semakna dengan ungkapan tersebut misalnya "'Sesungguhnya Allah Ta'ala adalah baik dan mencintai kebaikan, bersih dan mencintai kebersihan, mulia dan mencintai kemuliaan, dermawan dan mencintai kedermawanan. Maka bersihkanlah halaman rumahmu dan janganlah kamu menyerupai orang Yahudi." (HR. Tirmidzi) (Lihat Imam As-Suyuthi, Al-Jami' Ash-Shaghir, I/70)
} 
muncul, ada maupun timbul akibat proses alam yang berbentuk padat. ${ }^{8}$ Hal ini berbeda dalam pandangan Rudi Hartono ${ }^{9}$ yang memandang bahwa sampah tidak muncul akibat proses alam, atau dengan kata lain bahwa materi-materi yang muncul akibat proses alam tidaklah dinamakan sampah, sebab yang ada hanyalah produk-produk yang tidak bergerak.

Sampah (waste) dalam pengertian yang tidak jauh berbeda dikemukakan oleh Kuncoro $^{10}$, yaitu sebagai bahan yang dibuang atau terbuang; merupakan hasil aktivitas manusia atau alam yang sudah tidak digunakan lagi karena sudah diambil unsur atau fungsi utamanya. Sebagai hasil dari aktivitas manusia, maka besar kecil atau banyak tidaknya, timbulan sampah akan tetap ada selama manusia masih beraktivitas. Akan tetapi menurut Anwar, aktifitas yang dilakukan manusia (termasuk kegiatan industri) bukanlah aktifitas biologis karena kotoran manusia (human waste) tidak termasuk ke dalam kategori sampah.

Selain pengertian sampah secara umum yang sering digunakan untuk menyatakan limbah padat, sampah didefinisikan pula berdasarkan sudut pandang lainnya. Dalam sudut pandang ekonomi misalnya, sampah diartikan sebagai sisasisa bahan yang mengalami perlakuan-perlakuan, baik karena sudah diambil bagian utamanya, atau karena pengolahan, atau karena sudah tidak ada manfaatnya yang ditinjau dari segi social ekonimis tidak ada harganya ${ }^{11}$. Atau diartikan sebagai bahan yang terbuang atau dibuang dari hasil aktifitas manusia maupun proses alam yang belum memiliki nilai ekonomi.

Dari segi lingkungan, sampah dapat menyebabkan pencemaran atau gangguan terhadap lingkungan hidup. Menurut kamus istilah lingkungan hidup, sampah mempunyai definisi sebagai bahan yang tidak mempunyai nilai, bahan yang tidak berharga untuk maksud biasa, pemakaian bahan rusak, barang yang cacat dalam pembikinan manufaktur, materi berkelebihan, atau bahan yang ditolak. Senada dengan pengertian tersebut adalah definisi yang dinyatakan dalam SNI tahun 2002, yaitu :

${ }^{8}$ Lihat UU Nomor 18 tahun 2008 tentang Pengelolaan Sampah

${ }^{9}$ Rudi Hartono, Penanganan dan Pengolahan Sampah (TPS : Bogor, 2008), h. 5

${ }^{10}$ Kuncoro Sejati, Pengelohan Sampah Terpadu Dengan Sistem Node, Sub Point, Center Point (Kanisius : Yogyakarta, 2009), h. 12

11 S. Hadiwiyoto, Penanganan dan Pemanfaatan Sampah, (Yayasan Idayu : Jakarta 1983), h. 13

Jurisprudentie | Volume 4 Nomor 1 Juni 2017 
Sampah adalah limbah yang bersifat padat terdiri dari bahan organik dan bahan anorganik yang dianggap tidak berguna lagi dan harus dikelola agar tidak membahayakan lingkungan dan melindungi investasi pembangunan ${ }^{12}$ Berdasarkan beberapa pengertian tersebut terlihat bahwa sampah merupakan materi/bahan ${ }^{13}$ sisa atau lebih (baik oleh manusia maupun alam) yang tidak diperlukan, tidak berguna, tidak mempunyai nilai, serta tidak berharga yang akhirnya terbuang (dibuang) maupun ditolak, yang merupakan materi/bahan yang dapat mengganggu bahkan membahayakan (fungsi) lingkungan.

Sementara sumber timbulan/timbunan sampah tersebut berasal dari kegiatan penghasil sampah seperti pasar, rumah tangga, perkotaan (kegiatan komersial/ perdagangan), fasilitas-fasilitas umum lainnya, dan kegiatan lain seperti dari industri dengan limbah yang sejenis sampah. Secara umum sumber sampah di masyarakat terkait erat dengan memanfaatan lahan atau tempat pembuangan yaitu TPS maupun TPA. Beberapa sumber sampah dapat diklasifikasikan menjadi antara lain: perumahan, komersil, institusi, konstruksi dan pembongkaran, pelayanan jasa dan perkotaan, unit pengolahan, industri, dan pertanian/perkebunan.

\section{A. Sampah dan Permasalahannya}

Permasalahan pengelolaan persampahan menjadi sangat serius utamanya di perkotaan akibat kompleksnya permasalahan yang dihadapi dan kepadatan penduduk yang tinggi, sehingga pengelolaan persampahan sering diprioritaskan penanganannya di daerah perkotaan. Permasalahan dalam pengelolaan sampah yang sering terjadi antara lain perilaku dan pola hidup masyarakat masih cenderung mengarah pada peningkatan laju timbulan sampah yang sangat membebani pengelola kebersihan, keterbatasan sumber daya, anggaran, kendaraan personil sehingga pengelola kebersihan belum mampu melayani seluruh sampah yang dihasilkan ${ }^{14}$

Lalu mengapa sampah dianggap sebagai sebuah permasalahan ?. HR Sudrajat mengemukakan bahwa sampah merupakan permasalahan yang sangat

12 Badan Standardisasi Nasional, SNI 19-2454-2002 Tata Cara Teknik Operasional Pengelolaan Sampah Perkotaan, h. 1

13 Sumber sampah berdasar materinya dapat dibedakan menjadi : 1. organik, berupa buangan sisa makanan misalnya buah/sayur dan daging, 2. Anorganik, adalah merupakan sisa material sintetis berupa kaca, plastik maupn logam. Lihat, Cecep Dani Sucipto, Teknologi Pengolahan Daur Ulang Sampah, (Jakarta: Goysen Publishing, 2009), h. 2-3.

${ }^{14}$ http://www.repository.usu.ac.id. Diakses pada tanggal 3 Mei 2017 
penting khususnya bagi masyarakat perkotaan, dan hal ini dapat terjadi oleh beberapa faktor yaitu : ${ }^{15}$

1. Volume sampah sangat besar, melebihi kapasitas TPS dan TPA

2. Lahan TPA makin sempit tergerus oleh tujuan lain

3. Teknologi pengelolaan tidak optimal, menyebabkan kian membesarnya volume sampah dari pembusukan

4. Sampah yang sudah matang maupun kompos tidak dikeluarkan dari TPA

5. Manajemen pengelolaan sampah yang tidak efektif

6. Pengelolaan sampah dirasakan tidak membawa dampak positif terhadap lingkungan

7. Kurangnya dukungan kebijakan pemerintah.

Tak dapat dipungkiri, bahwa penumpukan sampah menjadi salah satu permasalah besar yang sama dihadapi oleh kota-kota besar sekaligus menjadi permasalahan lingkungan hidup, permasalahan sampah selalu hadir di setiap (sudut) kota, dimulai dari rumah tangga sampai pada tempat-tempat pembuangan/penampungan, baik di tempat pembuangan sementara (TPS), tempat pembuangan akhir (TPA), maupun saat pendistribusiannya. Berikut beberapa faktor penyebab penumpukan sampah yaitu : ${ }^{16}$

1. Volume sampah sangat besar dan tidak diimbangi oleh daya tampung TPA sehingga melebihi kapasitasnya

2. Jarak TPA dan pusat sampah relatif jauh hingga waktu untuk mengangkut sampah kurang efektif.

3. Fasilitas pengangkutan sampah terbatas dan tidak mampu mengangkut seluruh sampah.

4. Sisa sampah di TPS berpotensi menjadi tumpukan sampah.

5. Teknologi pengolahan sampah tidak optimal sehingga lambat membusuk.

6. Tidak semua lingkungan memiliki lokasi penampungan sampah, sehingga masyarakat sering membuang sampah di sembarang tempat sebagai jalan pintas.

7. Kurangnya sosialisasi dan dukungan pemerintah mengenai pengelolaan dan pengolahan sampah serta produknya.

\footnotetext{
${ }^{15}$ HR Sudrajat, Mengelola sampah Kota (Bogor: Niaga Swadaya, 2006), h. 6

16 Tim Penulis PS. Penanganan dan Pengolahan Sampah. (Jakarta: Penebar Swadaya,
} 2008), h. 13 
8. Minimnya edukasi dan manajemen diri yang baik mengenai pengolahan sampah secara tepat.

9. Manajemen sampah tidak efektif.

Permasalahan-permasalahan tersebut baik yang berasal dari keberadaan sampah itu sendiri, maupun yang terkait dengan penumpukan serta pengelolaannya, lebih jauh lagi akan membawa dampak dampak baru. Misalnya saja, dari sudut pandang estetika (kebersihan dan keindahan kota) maupun dari sudut sanitasi (kesehatan lingkungan). Tumpukan sampah yang tersebar tanpa mengenal tempat, memberikan kesan jorok, kotor, kumuh maupun rantasa'. Sementara dari sudut pandang kesehatan (lingkungan), keberadaan sampah dapat menjadi media berkembang biaknya bibit penyakit maupun menjadi media perantara menyebarluasnya suatu penyakit.

Suwerda mengemukakan beberapa dampak apabila sampah tidak dikelola dengan baik sebagai berikut ${ }^{17}$ :

1. Sampah dapat menjadi sumber penyakit, lingkungan menjadi kotor. Hal ini akan menjadi tempat yang subur bagi mikroorganisme patogen yang berbahaya bagi kesehatan manusia, dan juga menjadi tempat sarang lalat, tikus dan hewan liar lainnya.

2. Pembakaran sampah dapat berakibat terjadinya pencemaran udara yang dapat mengganggu kesehatan masyarakat, dan memicu terjadinya pemanasan global.

3. Pembusukan sampah apat menimbulkan bau yang tidak sedap dan berbahaya bagi kesehatan. Cairan yang dikeluarkan dapat meresap ketanah, dan dapat menimbulkan pencemaran sumur, air tanah, dan yang dibuang ke badan air akan mencemari sungai.

4. Pembuangan sampah kesungai atau badan air dapat menimbulkan pendangkalan sungai, sehingga dapat memicu terjadinya banjir.

\section{B. Kebijakan Pengelolaan Sampah}

Pada hakikatnya permasalahan sampah terkait erat dengan paradigma manusia sebagai diri pribadi maupun sebagai suatu kumpulan manusia (masyarakat). Sudah sejak dahulu kala manusia menghasilkan sampah. Lalu dengan paradigma yang masih sederhana, sampah yang dihasilkan tersebut dipandang sebagai sesuatu yang tak bernilai sama sekali, dan akhirnya dibuang.

${ }^{17}$ Bambang Suwerda, Bank Sampah: Kajian Teori dan Penerapannya (Pustaka Rihama : Yogyakarta, 2012), h.6 
Masalahnya lalu berlanjut, ketika materi tak bernilai dibuang disembarang tempat. Dalam pandangan ini, pengelolaan sampah dilihat sebagai kegiatan yang justru merugikan, sebab akan menyita waktu, tenaga bahkan membutuhkan uang.

Lebih jauh lagi, dalam pandangan Setyo Purwendo dan Nurhidayat menyatakan bahwa akar permasalahan sampah di satu sisi terkait erat dengan budaya masyarakat yang tercermin dari kurangnya disiplin dan masih rendahnya kesadaran menjaga lingkungan. Di sisi lain, terkait dengan lemahnya kebijakankebijakan pemerintah dalam pengelolaan sampah, yang terlihat dari peraturanperaturan maupun koordinasi antar instansi pemerintah. ${ }^{18}$

Hal tersebut cukup tepat dan beralasan, setidaknya Undang-undang Nomor 18 tahun 2008 memberikan alasan yang senada, bahwa pengelolaan sampah selama ini belum sesuai dengan metode dan teknik pengelolaan sampah yang berwawasan lingkungan sehingga menimbulkan dampak negatif terhadap kesehatan masyarakat dan lingkungan, dengan demikian pengelolaan sampah perlu dilakukan secara komprehensif dan terpadu dari hulu ke hilir agar dapat mengubah perilaku masyarakat. Oleh sebab itu dalam pengelolaan sampah diperlukan kepastian hukum, kejelasan tanggung jawab dan kewenangan Pemerintah, pemerintahan daerah, serta peran masyarakat dan dunia usaha sehingga pengelolaan sampah dapat berjalan secara proporsional, efektif, dan efisien $^{19}$

Pengelolaan sampah berdasarkan Undang-undang Nomor 18 tahun 2008 dinyatakan sebagai usaha dan kegiatan yang sistematis, menyeluruh, dan berkesinambungan yang yang terdiri dari dua bagian yaitu pengurangan dan penanganan sampah ${ }^{20}$. Berdasarkan undang-undang ini pula diketahui bahwa sampah yang dikelola adalah sampah yang digolongkan ke dalam tiga golongan yaitu ; sampah rumah tangga, sampah sejenis rumah tangga maupun sampah spesifik $^{21}$.

Adapun asas pengelolaan sampah berdasarkan undang-undang ini adalah Pengelolaan sampah diselenggarakan berdasarkan asas tanggung jawab, asas berkelanjutan, asas manfaat, asas keadilan, asas kesadaran, asas kebersamaan,

${ }^{18}$ Setyo Purwndo dan Nurhidayat, Mengolah Sampah Untuk Pupuk Pestisida Organik (Penebar Swadaya : Jakarta, 2006), h. 10

19 Republik Indonesia, Undang-Undang Republik Indonesia Nomor 18 Tahun 2008 tentang Pengelolaan Sampah, menimbang huruf b, c dan d

${ }^{20}$ Republik Indonesia, Undang-Undang Republik Indonesia Nomor 18 Tahun 2008. Pasal 1 poin 5

${ }^{21}$ Republik Indonesia , Undang-Undang Republik Indonesia Nomor 18 Tahun 2008, Pasal 2 ayat (1)

Jurisprudentie | Volume 4 Nomor 1 Juni 2017 
asas keselamatan, asas keamanan, dan asas nilai ekonomi ${ }^{22}$. Sementara pengelolaannya ditujukan pada peningkatan kesehatan masyarakat dan kualitas lingkungan serta menjadikan sampah sebagai sumber daya ${ }^{23}$.

Berdasar pada pengertian pengelolaan sampah pada Pasal 1 poin 5, dapat difahami bahwa Pengelolaan sampah adalah semua kegiatan dan usaha-usaha yang dilakukan dan dilaksanakan dalam rangka memperlakukan dan menangani sampah sejak ditimbulkan sampai dengan pembuangan akhir. Yudhi mendefinisikan kegiatan di dalam pengelolaan sampah meliputi pengendalian timbulan sampah, pengumpulan sampah, transfer dan transport, pengolahan dan pembuangan akhir ${ }^{24}$. Oleh sebab itu, hal-hal terkandung di dalam penegertian pengelolaan sampah meliputi semua kegiatan yang bersangkut paut dengan pengendalian timbulnya sampah, pengumpulan, transfer dan transportasi, pengolahan dan pemrosesan akhir/pembuangan sampah, dengan mempertimbangkan faktor kesehatan lingkungan, ekonomi, teknologi, konservasi, estetika dan faktor-faktor lingkungan lainnya yang erat kaitannya dengan respon masyarakat

Secara garis besarnya di Indonesia dikenal 2 model pengelolaan sampah yaitu urugan dan tumpukan. Model urugan ini umumnya dilakukan pada daerah daerah yang tidak menghasilkan volume sampah dalam jumlah besar. Dalam model ini sampah dibuang di lembah atau cekukan tanpa ada perlakuan lebih lanjut, artinya sekedar dibuang lalu ditinggalkan ${ }^{25}$, model ini adalah model pengelohan sampah yang sangat sederhana bahkan dapat dikatakan sebagai model yang sedikit memodifikasi paradigma awal masyarakat umum terhadap sampah.

Adapun model kedua yaitu tumpukan yang cendrung lebih maju, untuk model pengelolaan sampah dengan tumpukan ini dilengkapi dengan unit saluran air untuk buangan, pengelolaan air untuk buangan (leachatte) dan pembakaran akses gas metan (flare). Model seperti ini sudah memenuhi persyaratan lingkungan dan banyak diterapkan di kota-kota besar, namun sayang model

\footnotetext{
${ }^{22}$ Republik Indonesia , Undang-Undang Republik Indonesia Nomor 18 Tahun 2008, Pasal 3

${ }^{23}$ Republik Indonesia , Undang-Undang Republik Indonesia Nomor 18 Tahun 2008, Pasal 4

24 Yudhi Kartikawan, Pengelolaan Persampahan, (Yogyakarta: Jurnal Lingkungan
} Hidup, 2009).

${ }^{25}$ HR Sudrajat, op.cit. , h. 10 
tumpukan ini tidak lengkap tergantung dari kondisi keuangan dan kepedulian pejabat daerah setempat akan kesehatan lingkungan dan masyarakat. ${ }^{26}$

Secara teoritik, untuk mengatasi persoalan sampah mengharuskan dilakukannya pergeseran pendekatan dari pendekatan ujung-pipa (end-pipe of solution) ke pendekatan sumber. Dengan pendekatan sumber, maka sampah ditangani pada hulu sebelum sampah itu sampai ke tempat pengolahan akhir/hilir. Terdapat beberapa konsep tentang pengelolaan sampah yang berbeda dalam penggunaannya, antara negara-negara atau daerah. Beberapa yang paling umum, yang merupakan multi konsep yang digunakan adalah: ${ }^{27}$

1. Hierarki sampah - hierarki sampah merujuk kepada " $3 \mathrm{M}$ " mengurangi sampah, menggunakan kembali sampah dan mendaur ulang sampah, yang mengklasifikasikan strategi pengelolaan sampah sesuai dengan keinginan dari segi minimalisasi sampah. Hierarki limbah yang tetap menjadi dasar dari sebagian besar strategi minimalisasi sampah. Tujuan hierarki sampah adalah untuk mengambil keuntungan maksimum dari produk-produk praktis dan untuk menghasilkan jumlah minimum limbah.

2. Perpanjangan tanggung jawab penghasil sampah (Extended Producer Responsibility). EPR adalah suatu strategi yang dirancang untuk mempromosikan integrasi semua biaya yang berkaitan dengan produkproduk para produsen di seluruh siklus hidup produk tersebut ke dalam pasar harga produk. EPR dimaksudkan untuk menentukan akuntabilitas atas seluruh siklus hidup produk dan kemasan yang dibawa ke pasar. Ini berarti perusahaan yang membuat, mengimpor dan/atau menjual produk diminta untuk bertanggung jawab atas produk mereka sejak manufaktur hingga akhir dari masa penggunaannya.

3. Prinsip pengotor membayar - prinsip pengotor membayar adalah prinsip di mana pihak pencemar membayar dampak dari aktivitasnya ke lingkungan. Sehubungan dengan pengelolaan limbah, umumnya merujuk kepada penghasil sampah untuk membayar sesuai dengan volume dan jenis sampah yang dibuang.

Konsep 3M sebagai yang disebutkan sebelumnya merupakan konsep yang diadopsi dari konsep 3R (reduce, recyle,re-use), konsep ini menurut HR

\footnotetext{
${ }^{26}$ HR Sudrajat, op.cit., h. 11

${ }^{27}$ https://id.wikipedia.org/wiki/Pengelolaan_sampah, diakses tanggal 10 Maret 2017
} 
Sudrajat $^{28}$ ini adalah konsep yang dipergunakan oleh beberapa negara, mengenai aturan tentang prakarsa manajemen sampah. Pengelolan sampah pada beberapa negara pada umumnya dimulai dari rumah tangga yaitu dengan memisahkan sampah organik dan anorganik ${ }^{29}$ dengan menggunakan wadah terpisah (biasanya ditandai dengan menggunakan simbol-simbol atau warna tertentu), adapun wadah/tempat yang digunakan adalah yang bisa didaur ulang.

Adapun di Indonesia, keberadaan konsep ini terlihat dalam Pasal 1 poin 5 Undang-undang No. 18 tahun 2008, lalu dinyatakan kembali melalui Pasal 19, bahwa pengelolaan sampah terdiri dari dua kegiatan yaitu pengurangan dan penanganan. Pengurangan sesuai dengan Pasal 20 ayat (1) dimaksudkan sebagai rangkaian kegiatan yang meliputi pembatasan timbulan sampah, pendauran ulang sampah; dan/atau pemanfaatan kembali sampah. Sedangkan kegiatan penanganan sampah meliputi kegiatan sebagai berikut :

1. Pemilahan dalam bentuk pengelompokan dan pemisahan sampah sesuai dengan jenis, jumlah, dan/atau sifat sampah;

2. pengumpulan dalam bentuk pengambilan dan pemindahan sampah dari sumber sampah ke tempat penampungan sementara atau tempat pengolahan sampah terpadu;

3. pengangkutan dalam bentuk membawa sampah dari sumber dan/atau dari tempat penampungan sampah sementara atau dari tempat pengolahan sampah terpadu menuju ke tempat pemrosesan akhir;

4. pengolahan dalam bentuk mengubah karakteristik, komposisi, dan jumlah sampah; dan/atau

5. pemrosesan akhir sampah dalam bentuk pengembalian sampah dan/atau residu hasil pengolahan sebelumnya ke media lingkungan secara aman. ${ }^{30}$

Berdasar pada materi undang-undang tersebut, cara pengelolaan yang dimaksud adalah pengelolaan dari hulu ke hilir dengan menerapkan prinsip 3R yaitu meliputi kegiatan pengurangan/pembatasan timbulan sampah (reduce), pemanfaatan kembali sampah (reuse) dan pendauran ulang sampah (recycle). Prinsip 3R yang diharapkan mampu mejadi cara pemecahan untuk mengurangi permasalahan tingginya volume timbulan/timbunan sampah di TPS (Tempat

${ }^{28}$ HR. Sudrajat, op.cit, h. 16

${ }^{29}$ Setyo Purwndo dan Nurhidayat, op. cit., h. 14

${ }^{30}$ Republik Indonesia , Undang-Undang Republik Indonesia Nomor 18 Tahun 2008, Pasal 22

Jurisprudentie | Volume 4 Nomor 1 Juni 2017 
Penampungan Sementara) dan keterbatasan daya tampung TPA (Tempat Penampungan Akhir). Sebab telah disadari bahwa penanganan permasalahan sampah yang kurang tepat dapat mengancam aspek keindahan kota dan pencemaran lingkungan serta masalah kesehatan.

\section{PENUTUP}

Timbulnya permasalahan sampah saat ini tidak terlepas dari perilaku warga masyarakat sebagai penghasil sampah, maupun lemahnya aturan terkait hal tersebut. Kenyataan di lapangan menunjukkan masih banyak warga masyarakat yang belum melakukan pengelolaan sampah di tingkat rumah tangga dengan baik, mulai dari memilah sampah, menyimpannya, dan membuang sampah pada tempatnya, sementara kelemahan aturan dan kordinasi antar lembaga disinyalir ikut memberi andil terhadap permasalahan tersebut.

Menjawab persoalan persampahan tersebut, maka dibuatlah berbagai opsi, berupa konsep konsep pengelolaan sampah, yang penekanannya terletak pada perubahan paradigma masyarakat secara umum dalam memandang sampah, misalnya dalam bentuk peran serta masyarakat dalam pengelolaan sampah. Disamping memperkenalkan berbagai model pengelolaan dan penanganan sampah yang dimulai dari rumah tangga sampai pada TPA dan akhirnya diperkuat melalui instrumen-intrumen hukum. 


\section{DAFTAR PUSTAKA}

Badan Standardisasi Nasional, SNI 19-2454-2002 Tata Cara Teknik Operasional Pengelolaan Sampah Perkotaan

Bambang Suwerda. 2012. Bank Sampah: Kajian Teori dan Penerapannya. Yogyakarta : Pustaka Rihama

Cecep Dani Sucipto. 2009. Teknologi Pengolahan Daur Ulang Sampah. Jakarta: Goysen Publishing

HR Sudrajat. 2006. Mengelola sampah Kota. Bogor : Niaga Swadaya

Jenna R Jambeck dan kawan-kawan (publikasi di www.sciencemag.org 12 Februari 2015) yang diunduh dari laman www.iswa.org pada 20 Januari 2016

Kuncoro Sejati. 2009. Pengelohan Sampah Terpadu Dengan Sistem Node, Sub Point, Center Point. Yogyakarta : Kanisius

Provinsi Sulawesi Selatan. 2015. Sulawesi Selatan Dalam Angka 2015. Makassar : Badan Pusat Statistik Prov. Sul-Sel

Republik Indonesia, Undang Undang No. 32 Tahun 2009 Tentang Perlindungan dan Pengelolaan Lingkungan Hidup.

Republik Indonesia, Undang-Undang Republik Indonesia Nomor 18 Tahun 2008 tentang Pengelolaan Sampah

Rudi Hartono. 2008. Penanganan dan Pengolahan Sampah. Bogor : TPS

S. Hadiwiyoto. 1983. Penanganan dan Pemanfaatan Sampah. Jakarta : Yayasan Idayu

Setyo Purwndo dan Nurhidayat. 2006. Mengolah Sampah Untuk Pupuk Pestisida Organik. Jakarta: Penebar Swadaya

Tim Penulis PS. 2008. Penanganan dan Pengolahan Sampah. Jakarta: Penebar Swadaya

Yudhi Kartikawan. 2009. Pengelolaan Persampahan. Yogyakarta : Jurnal Lingkungan Hidup

http://dukcapil-makassar.com/index.php/data-penduduk/list/2, diakses tanggal 8 Maret 2017 